Vol. 21 No. 2, (December 2021), pp. 113-128.

journal homepage: http://jaauth.journals.ekb.eg

\title{
The Impact of Adopting Guerrilla Marketing on Increasing the Market Share of EgyptAir Airlines
}

\author{
Ahmed Adel Hammad \\ Lecturer of Tourism Studies, Tourism Studies Department, \\ Faculty of Tourism and Hotels, Mansoura University
}

\section{ARTICLE INFO}

Keywords:

Marketing; Guerrilla Marketing; Egypt Air; Airlines.

(JAAUTH)

Vol. 21, No. 2, (December 2021), PP.113-128.

\section{ABSTRACT}

The market share that an airline companies has, depends on the marketing process of its products and services. Adopting untraditional ways of marketing can be one of the key factors towards achieving success for these companies. This research aims at clarifying the impact that guerrilla marketing can play as an untraditional marketing tool for increasing the market share of EgyptAir Airlines. By adopting guerrilla marketing, EgyptAir's tickets can be marketed in a unique, interesting and a low cost way, and as a result the company's market share will be increased. This research presents an investigation into the guerrilla marketing concept, its role and the extent of its adoption in EgyptAir Airlines. The research depended on primary data through carrying out interviews with eighteen members of the marketing and sales department at the senior management of EgyptAir Airlines. The research also depended on utilising different sources of secondary data related to its subject. The findings have revealed that guerrilla marketing is not widely adopted on EgyptAir Airlines except for the use of some signs, hoardings and logos' models of EgyptAir and Star Alliance in airports. The findings have also revealed that digital marketing is the marketing method that EgyptAir Airline basically depends on. Therefore, the research recommends adopting guerrilla marketing in EgyptAir Airlines to act as an ancillary form of marketing alongside the digital marketing and the other marketing practices that are already adopted in EgyptAir Airlines so that the market share of the company can be increased.

\section{Introduction}

The current competitiveness in the business environment is having a strong impact on the travel industry (Abdul-Hamid, 2011). Effective marketing tools have become an imperative necessity for confronting the stiff competition amongst airline companies (Shaw, 2007). Some airline companies have become very keen on adopting compelling marketing tools for attracting a large number of passengers and realising a genuine increase in their sales (Kotler, 2001; Kanagal, 2015). Guerrilla marketing is 
one of the effective marketing tools that brings about an apparent outcome for companies' sales with the lowest possible marketing costs (Yuniarto et al., 2020). It depends basically on utilising new advertising ideas instead of traditional or expected ones (Khare, 2017). This research investigates into the impact that guerrilla marketing has as an untraditional marketing tool for increasing the market share of EgyptAir Airline; the flag carrier of Egypt.

The research's core problem lies in finding a balance between guerrilla marketing practices, and the capability of EgyptAir Airlines in adopting them for increasing its market share in a unique cheap way. Therefore, carrying out a research combining those two variables is key.

The importance of research focuses on the guerrilla marketing and the extent of its implementation in EgyptAir Airline.

The research aims to clarify the guerrilla marketing concept, shed light on its importance and practices, measure the level of its adoption in EgyptAir Airline, and finally provide a set of suggestions and recommendations about its adoption in EgyptAir Airline.

Regarding the significance of adopting guerrilla marketing in EgyptAir Airline for increasing its market share, this research poses the following questions:

a- What are the most common marketing tools adopted in EgyptAir Airlines?

b- What are thee most effective marketing tools that achieved a real increase in the market share of EgyptAir Airline?

c- Does EgyptAir adopt guerrilla marketing as an untraditional low-cost way for increasing its market share?

d- If "no", what are the reasons impeding the adoption of guerrilla marketing in EgyptAir Airlines?

e- If you will apply guerrilla marketing for increasing the market share of EgyptAir Airlines, what kind of advertising messages you will depend on?

f- What are the benefits that EgyptAir Airlines can get in its market share by adopting guerrilla marketing?

\section{Literature Review}

\section{1- The concept and emergence of guerrilla marketing:}

The use of the word; guerrilla; sometimes spelt as guerilla, was chiefly associated with military ruses and political manipulations (Williams, 2018). It originally came from the Spanish word "guerra", which means War (Wendland, 2016). As a result, the term; guerrilla warfare appeared to refer to gangs' war (Airbowo \& Risman, 2020). Cambridge advanced learner's dictionary (2005) mentioned to the word; guerrilla as "political actions that aim to make attacks on foes through ploys". On the other side, the dictionary referred to guerrilla when it comes as an adjective, as "the use of unfamiliar low-cost ways to attract people's interest in new products or services". 
Guerrilla marketing was first introduced in 1983 by the American business writer; Jay Conrad Levinson, in his book entitled; Guerrilla Marketing (Levinson, 1984). Instead of extensive marketing campaigns that other forms of marketing depend on, guerrilla marketing utilises unexpected communications, interactions and/or surprises on streets and public places for marketing a certain product or service (Marrgolis \& Garrigan, 2008; Das et al., 2019; Gedik, 2020). It focuses on the distraction of people by diverting their attention to an unexpected kind of advertisement (Adizova et al., 2011). The untraditional advertising messages of guerrilla marketing give a greater chance for a business success, as it is keen on the long-lasting image of the advertisement in people's minds (Ay et al., 2010; Takwi et al., 2020). Guerrilla marketing depends on low-cost advertisements (Katke, 2016) that are based on the human psychological factor for paying people's attention to unfamiliar or shocking advertising messages for increasing the tendency in buying the product and talking about it with others (Saraf \& Joseph, 2019; Ahmed et al., 2020). Therefore, it can be inferred that guerrilla marketing depends also on the word of mouth amongst people after sending the advertising message to them (Nufer, 2013a; Tam \& Khuong 2015). Guerrilla marketing can play a positive impact on the purchasing decision of consumers depending on the uniqueness, directness, unexpectedness, artistic taste and sense of humour of its advertising message (Powrani \& Kennedy, 2018). As mentioned before, it is very cost-effective, so small and medium-sized enterprises utilises it due to their limited financial resources (Yüksekbilgili, 2014). However, large organisations are now adopting guerrilla marketing to raise people's awareness of their brands as well as to emphasise their level of competition in the market (Sajoy, 2013; Akandere, 2014). Instances of guerrilla marketing campaigns are organised by different famous large companies. They include for instance, when the Polish beer brand; Tyskie, hung the image of its Tyskie beer glass on a shop's door and utilised the real door's handle to act as the beer glass's handle. Nestle promoted its Kit Kat chocolate depending on guerrilla marketing, when it utilised a large model of this chocolate bar to act as a seat in a public garden (Jurčić, 2017). Unilever Company utilised an enlarged picture of its Lipton tea bag to act as a shopping bag (Onurlubaş, 2017). McDonald's also depended on guerrilla marketing when it utilised a huge model of its famous crisps to act as a speed hump and as a pedestrian crossing on the way leading to McDonald's (Choudhury, 2019).

\section{2- Central Points of guerrilla marketing:}

Guerrilla marketing is dependent on some tools represented in other forms of marketing, so it can send its marketing message in an interesting way (Nufer, 2013b). These other forms of marketing include ambient marketing, sensory or sensation marketing, buzz marketing, viral marketing and ambush marketing (Ujwala, 2012), as indicated in the following points: 


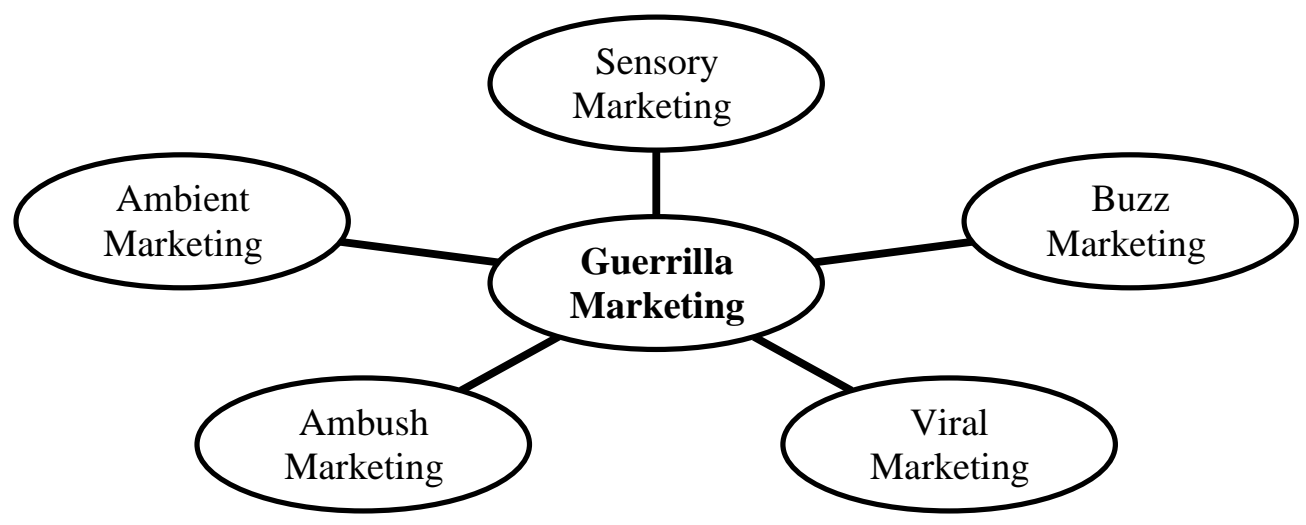

Fig.1. Central Points of Guerrilla Marketing

Source: (Ujwala, 2012)

a- Ambient marketing: it is that form of marketing that depends on the communication and reaction of persons towards an unusual way of advertising for a certain product or service in a not expected place (Shelton et al., 2016). The core of its successfulness is highly dependent on the uniqueness, innovation, creativity, surprise and even hilarity of its advertising message (Othman, 2020). Its fundamental role is to catch people's attention to the offered product or service, so that they can accept it, interact with it and transfer it to others (Sorrentino, 2020).

b- Sensory marketing: it is that form of marketing that depends on the communication with people through their five senses; hearing, sight, smell, taste and touch, in its advertising campaign (Erenkol \& Ak, 2015). The fundamental goal of sensory marketing is to convey a message to the customer depending on the interest creation, the buying temptation, and the relationship creation between both of the customer and the product/service (Dissabandara \& Dissanayake, 2019). It is an effective way to look for customers and convince them to buy the offered product or service by providing them a part of experiencing it (JiménezMarín et al. 2019).

c- Buzz marketing/Viral marketing: it is that form of marketing that depends on paying people's attention to a certain product/service and motivating them to talk about it either by word of mouth or sharing information about it through different forms of social media (Miller \& Lammas, 2010; Lekhanya, 2014, Soundararaj et al., 2015; Campbell et al., 2017). The fundamental goal of buzz marketing is to boost people's awareness of the product or service and spread it through the feeling of excitement, energy and pleasure (Hashem, 2021).

d- Ambush marketing: it is that form of marketing that exploits a big or major event e.g. a major football match, as a path for advertising products or services against other competitors without paying any advertising costs (Gulati, 2016). It emerged from the violent competition amongst companies, and as a result the fundamental goal of companies is to ambush their sponsor rivals in important 
events by giving a remark of their slogan or logo without being an official sponsor to that event (Johnson, 2020; Tomanek, 2020).

According to Hutter and Hoffmann (2011), guerrilla marketing depends basically on the surprise, diffusion and low cost effects, as follow:

a- Customers can be surprised when their eyes are caught to a certain advertising message because of its unexpected guerrilla way that depends on sensory marketing and ambient marketing.

b- Customers can diffuse or spread the advertising message, which raised their interest and attracted their attention through buzz marketing or viral marketing.

c- The guerrilla marketing is a low budget form of marketing as its message is presented one time unexpectedly and it does not require high costs depending on ambush marketing.

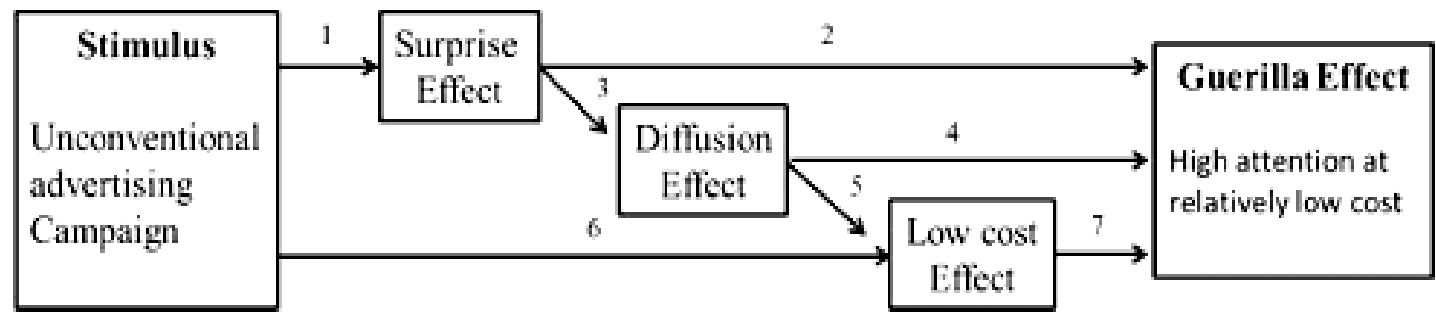

Fig.2.Guerrilla Marketing Stimuli and Effects

Source: (Hutter and Hoffmann, 2011)

According Baltes and Leibing (2008), there are some skilful focuses that companies should depend on when adopting guerrilla marketing:

a- Focusing on the advertising message i.e. the company should carry out a big catchy advertising campaign at the proper place to attract people's attention rather than carrying out many costly advertising campaigns.

b- Focusing on the company's ideology i.e. the company should introduce the service or product to the customer without neglecting its ideology and deal with the customer as a part of it and not vice versa.

c- Focusing on the advertising uniqueness i.e. the company should create a variation amongst its advertising styles for marketing two of its products/services.

d- Focusing on the difference i.e. the company should look for different and out of the box advertising ways, instead of the usual ones that other forms of marketing apply to reach to customers.

e- Focusing on the influence i.e. guerrilla marketing should always look for creating a true impact on customers through its distinct advertising message.

f- Focusing on the flexibility and agility i.e. guerrilla marketing should be able to change or be changed easily according to the situation to assure the complete 
success, particularly when its advertising message is unusual and not presented in the same way of others'.

g- Capitalising on customers' bad notions about the product/service i.e. the company must confront the customers' notions that can be formed too early, specially without enough thought or knowledge, and clarify to them the reason behind its existence.

\section{3- The discrepancies between guerrilla marketing and traditional marketing:}

According to Mughari (2011), Isaac (2014) and Akandere (2014), it can be inferred that guerrilla marketing differs from traditional marketing as indicated in the following table (1):

Table 1

Guerrilla Marketing versus Traditional Marketing

\begin{tabular}{|l|l|}
\hline \multicolumn{1}{|c|}{ Guerrilla Marketing } & \multicolumn{1}{c|}{ Traditional marketing } \\
\hline Suitable for small and big companies. & Suitable for big companies. \\
\hline $\begin{array}{l}\text { Marketing campaigns do not require a lot } \\
\text { of money. }\end{array}$ & $\begin{array}{l}\text { Marketing campaigns do require a lot of } \\
\text { money. }\end{array}$ \\
\hline $\begin{array}{l}\text { Dependent on other forms of marketing, } \\
\text { which are its tools. }\end{array}$ & $\begin{array}{l}\text { Independent and a self-contained } \\
\text { marketing. }\end{array}$ \\
\hline $\begin{array}{l}\text { Explains the idea in an interesting new } \\
\text { way. }\end{array}$ & Explains the idea in a monotones way. \\
\hline Dependent on the psychological factor. & Dependent on the experience. \\
\hline $\begin{array}{l}\text { Focuses on the pleasure of people for } \\
\text { creating their approval and satisfaction } \\
\text { towards the advertised product/service. }\end{array}$ & $\begin{array}{l}\text { Focuses on carrying out marketing by } \\
\text { usual means of promotion. }\end{array}$ \\
\hline $\begin{array}{l}\text { Creates an interest followed by a desire in } \\
\text { buying the product/service. }\end{array}$ & Common and not very interesting. \\
\hline
\end{tabular}

\section{4- Marketing in airline companies}

Marketing has become the basic function of all business organisations (Theodossiou $\&$ Chrisa, 2007). Based its role, individuals can satisfy their needs and requirements by creating, offering, and exchanging valuable products and services (Kotler et al., 2015). Marketing is a set of processes that are carried out in an organised way to communicate, create, exchange and deliver offerings that can add value for both of customers and society (AMA, 2013). Accordingly, marketing tools have become necessary for all different activities (Hossain and Rahman, 2017). In the current competitive business environment, companies have become keen on utilising many advertising messages to convince customers to buy their offered products and/or services. Moreover, in the current era of internationalisation, globalisation and digitisation, traditional forms of marketing and advertising e.g. advertisements in magazines, newspapers, hoardings, trade fairs, television, radio and direct mail (Bhayani \& Vachhani, 2014; Balážiová, \& Spálová 2020) became relatively obsolete and cannot effectively be consistent with new variables of life (Akdoğan \& Altuntaş, 2015; Geraghty \& Conway 2016). Furthermore, traditional forms of marketing can cause a lack of interest amongst customers towards the advertising messages, 
particularly when customers encounter many of these monotonous messages in a frequent way (Tümer, et al., 2019). Thus, it is important to get them replaced by better unconventional forms of marketing e.g. guerrilla marketing (Nahar \& Adithya, 2017). The airline industry developed over the years when travelling by air became one of the common ways of travelling amongst a large segment of people (Chen et al., 2008). As a result, the competition amongst airline companies intensified as each airline wants to attract the largest proportion of the target passengers (Kilinc et al., 2012; Adeniran, 2016). Hence, marketeers in airline companies have primarily focused on attracting different passengers of various travel purposes depending on various forms of marketing (Camilleri, 2018). Airline companies also depend on the quality of their offered services to passengers and the safety of their flights as a way of marketing, particularly when these information are transferred amongst passengers through the word of mouth (Reddy \& Singh, 2019). Green marketing is another marketing form that some airlines do apply e.g. Flybe, EasyJet and Virgin Atlantic through implementing environmentally friendly practices in their flights and in all their provided services to passengers (Mayer et al., 2014). As to EgyptAir Airlines, its marketing process is done through the general administration of marketing, which is divided into the publicity administration, the administration of marketing communications and the administration of marketing programmes (EgyptAir, 2021). In the current technological age, airlines depend on adopting different forms of digital marketing through the use of their official electronic website, social media, applications of mobile phones and advertisements of search engines (Karaağaoğlu \& Çiçek, 2019; Boix \& Sánchez, 2021). As a result, EgyptAir Airlines has an administration for digital marketing, which is responsible for operating its digital marketing processes (EgyptAir, 2021). By browsing the electronic website of EgyptAir Airlines, it was found that the site includes all information that passengers need about the company and its services, which are presented in seven languages (http://www.egyptair.com). According to EgyptAir's annual report (2018-2019), EgyptAir Airlines has applied the mobile portal as a new service to be utilised by passengers through smart phones. This service is regarded as an application of digital marketing as it helps in digitally saving the boarding card on the passenger's smart phone, provide updated information about check-in times, timetables, luggage, classes, offers, latest news and the access to social media pages of the company. However, digital marketing can be confined to people who are skilled in utilising the internet and able to browse the electronic website of the airline (Almendros et al., 2015). Furthermore, EgyptAir Airlines is one of the airline companies that is keen on enhancing its brand name by carrying out continuous improvements in passengers' services to increase their satisfaction (Ashour et al., 2020). It has adopted some strategies for facilitating its air aviation, which acted as an indirect form of marketing. One of these strategies was joining the Star Alliance, which helped in affirming its brand name in the airlines' market and resulted in realising a noticeable increase in the number of its passengers as well as in its market share (O'Connell \& Warnock-Smith, 2012). 


\section{Methodology}

The airlines environment is characterised by its competitiveness and dynamism. The marketing process of an airline is important for defining products and determining the sales' method (Misetic et al., 2007). Considering the important role that guerrilla marketing plays as untraditional form of marketing for small-sized and large-sized companies, this research utilised a mixed methodology through incorporating both of primary and secondary data. The secondary sources were discussed above and included theoretical studies which are related to the subject of study. The primary data depended on the qualitative method, and were gathered and presented after conducting interviews with the total (18) members of the marketing and sales department at the senior management of EgyptAir Airlines; including the sales and marketing manager, the digital marketing manager, the marketing research specialist as well as (15) marketing executives. The interview was conducted with the mentioned interviewees in the period from $26^{\text {th }}$ of June 2021 to $29^{\text {th }}$ of July 2021. Because of the importance of EgyptAir Airlines as the flag carrier of the Arab Republic of Egypt (Samy, 2016), it was chosen to be the place for carrying out the field study. The interview questions consisted of (6) questions about the extent of guerrilla marketing adoption in EgyptAir Airlines and its role in increasing its market share, as follow:

\section{1- The most common marketing tools adopted in EgyptAir Airlines:}

Interviewees answered that EgyptAir Airlines always tries to adopt the most effective marketing methods that aim to attract the largest proportion of passengers for increasing its tickets' sales and market share. The company is keen on advertising its services, the newest innovations and updates it implements. They explained that in the past years, EgyptAir Airlines depended on traditional forms of marketing and promotion such as publications e.g. pamphlets, fliers, the annual report of EgyptAir Airlines, and its periodical magazine; Horus, which gives travel information as well as information about EgyptAir and its recent services. A two-minutes television advertisement about EgyptAir Airlines was also utilised as a way to remind people with EgyptAir, its logo and slogan, which is quite important for keeping the company's mental image. When EgyptAir Airlines joined Star Alliance in 2008, which is the world's largest global airline alliance, this has played a crucial role in increasing its tickets' sales through co-chairing and tickets' conjunction with other member airlines, and this acted as another form of marketing in EgyptAir Airlines. The marketing process of EgyptAir Airlines also depends on the sales' promotion through its participation in some important events related to the airline industry e.g. IATA fairs. Furthermore, free or discounted tickets that are offered to passengers in some occasions e.g. the mother's day and the $23^{\text {rd }}$ of July day, also act as a kind of marketing.

Interviewees emphasised that at the present time, EgyptAir Airlines is highly dependant on digital marketing as it is one of the most effective forms of marketing in the current technological era. This has come by creating the official website of EgyptAir that includes all information and data that passengers need, its social media pages on Twitter and Facebook, its official Youtube channel and its passengers' e- 
mail list that is used to send promotional advertisements about the company to its passengers. They also noted that, the current dependence of EgyptAir Airlines on digital marketing comes alongside the mentioned traditional marketing methods that have been applied by the company's marketing team for years ago.

\section{2- The most effective marketing tools that achieved a real increase in the market share of EgyptAir Airlines:}

Interviewees stated that digital marketing constitutes the most important marketing tool at the present time. Simply, by browsing the electronic website of EgyptAir Airlines, passengers can get information about everything they need e.g. timetables, itinerary, travelling classes, in-flight services, flights' durations, flights' stopovers, special offers, special requests, meals, and everything they could ask for about flights. Furthermore, they can book the flight and get their PNR; Passenger Name Record, at anytime from any place.

\section{3- The adoption of guerrilla marketing in EgyptAir Airlines as an untraditional low-cost way for increasing its market share:}

Interviewees answered that despite the role that guerrilla marketing plays in the marketing process of many companies, it is not widely adopted in airlines. EgyptAir Airlines is not highly dependant on guerrilla marketing as it is not clearly included in its marketing plan. However, sometimes EgyptAir Airlines depends on sensory marketing in airports either in Egypt or abroad by utilising catchy hoardings and signs about EgyptAir's passenger's cabin, cabin crew, classes, meals and other associated services. Furthermore, models of EgyptAir's logo with the Star Alliance logo and some models of its aeroplanes can be also found in airports.

\section{4- If "no", the reasons impeding the adoption of guerrilla marketing in EgyptAir} Airlines:

Interviewees stated that adopting new marketing tools other than those that are stipulated in the marketing plan of EgyptAir Airlines constitutes a challenge; represented in the need of a new kind of marketeers and some administrative procedures to approve and implement the new marketing strategy. They also mentioned that guerrilla marketing can be more effective for a special kind of companies e.g. food and beverages companies, restaurants and coffee bars. Is it not convenient enough to be adopted as a main marketing strategy in airline companies. However, they declared that guerrilla marketing can be adopted as a supplementary form of marketing alongside other forms of marketing in EgyptAir Airlines e.g. digital marketing, but not as a sole form of marketing. In other words, it can be adopted as an additional form of marketing for realising a more widespread existence for the brand name of EgyptAir Airlines, with the basic marketing tools that are already adopted in the company.

5- The kind of advertising messages that EgyptAir Airlines will depend on if it will apply guerrilla marketing for increasing its market share:

Interviewees stated that directing unconventional messages at places where a large number of potential passengers could exist is key. These places could be for instance airports, business districts and shopping centres. Therefore, sending catchy 
advertising messages in these places is important. These massages could be, for instance, by utilising catchy electric hoardings about EgyptAir Airlines' services, more models of its newest aeroplanes and models of EgyptAir's aeroplanes' seats to act, for instance as seats in a newly opened coffee bar.

\section{6- The benefits that EgyptAir Airlines can get in its market share by adopting guerrilla marketing:}

Interviewees stated that the interesting and attractive advertising messages that guerrilla marketing presents could help in revealing more positive facts about EgyptAir Airlines, its services, and its newest innovations in a more memorable way. This will help in increasing talks about EgyptAir Airlines amongst a large proportion of people either verbally or through social media, which can help in encouraging a new category of potential travellers to utilise EgyptAir Airlines as their carrier. Therefore, the adoption of guerrilla marketing can also help in widely increasing its brand name and level of competition with other airline companies, and this for sure will reflect positively on its market share.

\section{Conclusion}

This paper has presented an investigation into the impact of adopting guerrilla marketing on increasing the market share of EgyptAir Airlines. Regarding both of theoretical and practical parts of this research, it was found out that guerrilla marketing is not a new marketing tool, as it dates back to the eighties of the last century. However, in the current years, guerrilla marketing plays an important role in increasing sales and market share of small and medium-sized companies. Furthermore, it is applied in large-sized companies for retaining their brand name and increasing their market share. Guerrilla marketing depends on the use of interesting and untraditional advertising messages that catch people's attention towards them. Regarding EgyptAir Airlines, it was found out that guerrilla marketing is not highly adopted in it, whilst digital marketing is mainly adopted. However, sometimes EgyptAir Airlines launches sensory marketing campaigns in airports, which depends on catchy hoardings and signs about its flights and models of its logo and aeroplanes. It has been found out that guerrilla marketing can be added as an ancillary role with the basic role that digital marketing and other forms of marketing play in the company's marketing process. If the unconventional advertising messages of guerrilla marketing will be precisely adopted in EgyptAir Airlines, they will encourage people to watch it, talk about it and use the company as a carrier. This will increase the brand name of the company, its sales and consequently its market share.

Recommendations addressed to the marketing and sales department at the senior management of Egypt Air Airlines:

- Eliminating unnecessary bureaucratic procedures and red tape that impede the application of new or unconventional marketing strategies.

- Increasing the number of the qualified members in the marketing and sales department, who are aware of varied and unconventional forms of marketing. 
- Increasing the co-operation amongst EgyptAir Airlines, other marketing agencies and marketing experts in order to benefit from their expertise and apply more effective and unconventional marketing strategies e.g. guerrilla marketing.

- Hiring marketeers who are aware of the guerrilla marketing mix i.e. ambient marketing, sensory marketing, buzz marketing, viral marketing and ambush marketing, in order to be aware of its vital practices and effective adoption.

- Conducting guerrilla marketing researches in order to be able to identify different patterns of guerrilla marketing and adopt them in an effective way, as well as to determine and focus on the target people.

- Adopting guerrilla marketing to act as a supplementary marketing strategy alongside other marketing strategies which are adopted in EgyptAir Airlines.

- Determining which tool of guerrilla marketing would be the best to reach to the target people and leave a continuing impression.

- Creating an advertising guerrilla message involving the following characteristics which are the unexpectedness, creativity, clarity, conciseness and interactivity with the target people in order to attain the desired goals.

- Exploiting the most effective places e.g. airports and shopping centres either in Egypt or abroad for sending the guerrilla marketing message so that potential passengers of EgyptAir Airline can be attracted to it.

- Exploiting important tourism and airlines' events e.g. conferences, exhibitions and fairs for sending the guerrilla marketing message of EgyptAir Airlines by, for instance, creating attractive signs, hoardings and action figures about Egypt Air Airlines, its services and its staff to be utilised at these events.

- Inviting some celebrities and public figures, for instance to put on the logo and slogan of EgyptAir Airlines in major important events instead of being a formal sponsor to that event.

\section{References}

- Abdul-Hamid, I. (2011). Travel Agencies Strategies for Managing the Current Dynamic Environment, SEGi Review, 4(1), 71-79. ISSN 1985-5672.

- Adeniran, J. A., Egwuonwu, T. K. \& Egwuonwu, C. O. (2016): The Impact of Sales Promotion on Sales Turnover in Airlines Industry in Nigeria, International Journal of Marketing Studies, 8(3), 99-110.

- Adizova, N., Kadirov, U. \& Kadirov, D. (2011). Effectiveness of Non-Traditional Advertising: Intention Gap and Its Antecedents, ANZAM, 383, 1-9.

- Ahmed, R. R., Qureshi, J. A., Štreimikiene, D., Vveinhardt, J. \& Soomro, R. H. (2020): Guerrilla Marketing Trends for Sustainable Solutions: Evidence from SEMBased Multivariate and Conditional Process Approaches, Journal of Business Economics and Management, 21(3), 851-871.

- Airbowo, T., Risman, H. (2020). The Comparison of Guerilla Warfare Framework of Mao Tse-Tung, Vo Nguyen Giap, and Che Guevara, Asian Institute of Research, Journal of Social and Political Sciences, 3(4), 1082-1091. 
- Akandere, G. (2014). Marketing Strategy for Business which Serve in Logistic Sector: Guerilla Marketing, $12^{\text {th }}$ International Academic Conference, Prague, Czech Republic, 1-11.

- Akdoğan, M. S. \& Altuntaş, B. (2015). Covert Marketing Strategy and Techniques, Procedia - Social and Behavioral Sciences, 207, 135-148.

- Almendros, E. C., García, S. D. \& Pilar, J. M. (2015). What Type of Online Sales Promotion Do Airline Users Prefer?: Analysis of the Moderating Role of Users' Online Experience Level, Tourism \& Management Studies, 11(1), 52-61.

- AMA American Marketing Association (2013). Definitions of Marketing. In: https://www.ama.org/the-definition-of-marketing. Accessed on: 18 June 2021; 06.27 PM.

- Ashour, A. A., Hammoud, G. A. \& Tawfik, H. F. (2020). Egypt Air Strategic Turnaround Decisions for Recovery and Transformation, Journal of Tourism and Sorts Management, 3(2), 256-268.

- Ay, C., Aytekin, P. \& Nardali, S. (2010). Guerrilla Marketing Communication Tools and Ethical Problems In Guerilla Advertising, American Journal of Economics and Business Administration, 2(3), 280-286.

- Balážiová, I. \& Spálová L. (2020). Terminological and Historical Background of Guerilla Marketing as a Marketing Communication Strategy, Sciendo Social Communication, 1, 81-92.

- Baltes, G. \& Leibing, I. (2008). Guerrilla Marketing for Information Services, New Library World, 109(1/2), 46-55.

- Bhayani, S. \& Vachhani, N. V. (2014): Internet Marketing vs. Traditional Marketing: A Comparative Analysis, FIIB Business Review, 3(3), 53-63.

- Boix, J. C. \& Sánchez, M. P. (2021). Digital Marketing Management Applied to the Tourism Industry: Vueling Airlines Case Study, Journal of Tourism and Heritage Research, 4(2), 9-30.

- Cambridge Advanced Learner's Dictionary, $2^{\text {nd }}$ Ed., (2005). Cambridge University Press, UK.

- Camilleri, M. A. (2018). The Airline Business. In: Travel Marketing, Tourism Economics and the Airline Product, Chapter 10, Springer Nature, Cham, Switzerland, pp. 167-177.

- Campbell, A., Mayzlin, D. \& Shin, J. (2017). Managing Buzz, RAND Journal of Economics, 48(1), 203-229.

- Chen, H., Peng, N. \& Hackley, C. (2008). Evaluating Service Marketing in Airline Industry and its Influence on Student Passengers' Purchasing Behaviour-using TaipeiLondon Route as an example, Journal of Travel and Tourism Marketing, 25(2), 149160.

- Choudhury, R. R. (2019). Guerrilla Marketing: Small Money Big Reach, Journal of Emerging Technologies and Innovative Research, 6(7), 693-701.

- Das, J., Jagga, P. \& Choudhury, R. R. (2019). Guerrilla Marketing: Small Money Big Reach, Journal of Emerging Technologies and Innovative Research, 6(7), 693-701.

- Dissabandara, D. R. \& Dissanayake, D. M. R. (2019). Theoretical Review on Sensory Marketing, International Journal of Current Research, 11(7), 5361-5364.

- EgyptAir. In: http://www.egyptair.com. Accessed on: 09/07/2021; 05.34 AM. 
- EgyptAir (2018-2019). Annual Report.

- EgyptAir (2021): Organization Manual According to Integrated Management Systems, pp.10-11.

- Erenkol, A. D. \& Ak, M. (2015). Sensory Marketing, Journal of Administrative Sciences and Policy Studies, 3(1), 1-26.

- Gedik, Y. (2020). Guerilla Marketing: A Theoretical Framework on Its Tools, Advantages and Strategies, Cag University Journal of Social Sciences, 17(2), 68-86.

- Geraghty, G. \& Conway, A. (2016). The Study of Traditional and Non-Traditional Marketing Communications: Target Marketing in the Events Sector. Paper presented at the $12^{\text {th }}$ Annual Tourism and Hospitality Research in Ireland Conference, THRIC, Limerick Institute of Technology, Ireland.

- Gulati, S. (2016). Ambush Marketing: The Unofficial Free riding, International Journal of Research - GRANTHAALAYAH, 4(9), 45-54.

- Hashem, T. N. (2021). Thee Role of Buzz Marketing in Increasing Attention Towards Green Products: Moderating Role of Shockvertising, Journal of Contemporary Issues in Business and Government, 27(2), 1785-1798.

- Hossain, S. \& Rahman, F. (2017). Tools of Online Marketing, International Journal of Science and Business, 1(1), 1-7.

- Hutter, K., \& Hoffmann, S. (2011). Guerrilla Marketing: The Nature of the Concept and Propositions for Further Research. Asian Journal of Marketing, 5(2), 39-54.

- Isaac, A. A. (2014). Analysis of Guerrilla and Traditional Marketing Interface in Small and Medium Size Enterprises (SME) in Nigeria, Journal of Small Business and Entrepreneurship Development, 2(1), 175-190.

- Jiménez-Marín, G., Bellido-Pérez, E. \& López-Cortés, A. (2019). Sensory Marketing: The Concept, its Techniques and its Application to the Point of Sale. "Marketing Sensorial: El Concepto, sus Técnicas y su Aplicación en El Punto de Venta", Vivat Academia. Revista de Comunicación, 148, 121-147. In: http://www.vivatacademia.net/index.php/vivat/article/view/1177. Accessed on: 22/06/2021; 02.38. AM.

- Johnson, P. (2020). Defining the Indefinable: Legislating for Ambush Marketing, Editorial, Journal of Intellectual Property Law and Practice, 15(5), 313-314.

- Jurčić, I. (2017). Basic Marketing Issues for Start-up Companies: An Accent on Digital Marketing. In: https://www.researchgate.net/publication/312869070_Basic_marketing_issues_for_st art_up_companies___an_accent_on_digital_marketing. Accessed on: 26/06/2021.

- Kanagal, N. B. (2015). Innovation and Product Innovation in Marketing Strategy, Journal of Management and Marketing Research, 18, 1-25.

- Karaağaoğlu, N. \& Çiçek, Me. (2019). An Evaluation of Digital Marketing Applications in Airline Sector, Journal of Human Sciences, 16(2), 606-619.

- Katke, K. (2016). Guerrilla Marketing for Effective Marketing Communication: A Special Reference to Social Media Marketing, Asia Pacific Journal of Research, 1(41), 151-157.

- Khare, A. K. (2017). Guerilla Marketing: Innovation and Futuristic Approach Towards Marketing, International Journal of Advanced Engineering, Management and Science, 3(5), 420-426. 
- Kilinc, I., Oncu, M. A. \& Tasgit, Y. E. (2012). A Study on the Competition Strategies of the Airline Companies in Turkey, Tourismos International Multidisciplinary Journal of Tourism, 7(1), 325-338.

- Kotler, P. (2001). Marketing Management Millennium Edition, Pearson Custom Publishing, Boston, USA.

- Kotler, P., Keller, K. L., Brady, M., Goodman, M. \& Hansen, T. (2015). Marketing Management, $15^{\text {th }}$ Ed., Pearson Education Ltd.

- Lekhanya, L. M. (2014). The Impact of Viral marketing on Corporate Brand Reputation, International Business and Economics Research Journal, 13(2), 213-230.

- Levinson, J. C. (1984). Guerrilla Marketing: Secrets for Making Big Profits from Your Small Business, Houghton Mifflin, Boston, MA, USA.

- Margolis, J. \& Garrigan, P.(2008). Guerrilla Marketing for Dummies, Wiley Publishing Inc., Canada.

- Mayer, R., Ryley, T. \& Gillingwater, D. (2014). The Role of Green Marketing: Insights from Three Airline Case Studies, The Journal of Sustainable Mobility, 1, 4672.

- Miller, R. \& Lammas, N. (2010). Social Media and Its Implication for Viral Marketing, Asia Pacific Public Relations Journal, 11, 1-9.

- Misetic, I., Steiner, S. \& Tatalovic, M. (2007). Airline Marketing Factors, PrometTraffic \& Transportation, 19(1), 11-19.

- Mughari, A. M. (2011). Analysis of Guerrilla and Traditional Marketing Integration in Improving the Productivity of Organizational Marketing in Enterprises in Iran: A Case Study of Kaveh Industrial Estate in Iran, African Journal of Business Management, 5(3), 944-948.

- Nahar, P., \& Adithya, A. (2017). A Study on Effectiveness of Guerilla Marketing Among the People in Chennai City, International Journal of Innovative Research in Engineering and Multidisciplinary Physical Sciences, 6(5), 29-33.

- Nufer, G. (2013a). Guerrilla Marketing: Structuring the Manifestations and Critical Evaluation, Journal of Innovative Marketing, 9(2), 60-68.

- Nufer, G. (2013b). Guerrilla Marketing: Innovative or Parasitic Marketing?, Modern Economy, 4, 1-6.

- O'Connell, J. \& Warnock-Smith, D. (2012). Liberalization and Strategic Change in Air Transport: An Examination of Current and Future Variations in Tourist Traffic to and from Egypt Resulting from Policy Changes at EgyptAir. Tourism Economics, 18(4), 1-26.

- Onurlubaş, E. (2017): A Research on the Determination of Consumer Perceptions Related to Guerrilla Marketing Methods: Sample of Izmir Province, Emerging Marketing Journal, 7(1), 30-40.

- Othman, H. (2020). Ambient Ads as Unconventional Media Approach, International Design Journal, 10(2), 269-278.

- Powrani, K. \& Kennedy, F. B. (2018): The Effects of Guerrilla Marketing on Generation y Consumer's Purchase Intention, Asian Journal of Economics, Business and Accounting, 7(1), 1-12. 
- Reddy, V. B. \& Singh, A. (2019). Aviation Marketing, Centre for Aerospace and Defence Laws, Directorate of Distance Education, NALSAR University of Law, Hyderabad, India.

- Sajoy, P. B. (2013). Guerrilla Marketing: A Theoretical Review, Indian Journal of Marketing, 43(4), 42-47.

- Samy, H. (2016): Analyzing Traveller's E-Complaints: The Case of Egypt Air, Journal of the Association of Arab Universities for Tourism and Hospitality, 13(2), 37-50.

- Saraf, J. \& Joseph, J. (2019). The Impact of Guerrilla Marketing on Consumer's Purchase Intentions, New Horizon College of Engineering, National Conference on Management, Technology and Innovation in the VUC World, International Journal of Research and Analytical Reviews, Special Issue, 189-196.

- Shaw, S. (2007). Airline Marketing and Management, $6^{\text {th }}$ Ed., Ashgate Publishing Ltd., England, UK.

- Shelton, A. J., Wojciechowski, L. P. \& Warner, J. (2016). Ambient Marketing Practices in the United States: A Professional View, Communication Today, 7(1), 1-8.

- Sorrentino, M. (2020). How Ambient Marketing is Uniquely Placed to make Audiences Think, Westminster Papers in Communication and Culture, 15(2), 95-111.

- Soundararaj, J. J., Baskaran, S. A. \& Sivaprakkash, S. (2015). The Power of Buzz Marketing, Journal of Excusive Management Science 4(3), 1-13.

- Takwi, F. M., Sharon, B. E. A., Nchang, N. D., Cynthia, K. (2020). Guerilla Marketing Strategy for Neochurches in Cameroon, American Journal of Operation Management and Information Systems, 5(3), 49-55.

- Tam, D. D. \& Khuong, M. N. (2015). The Effects of Guerilla Marketing on Gen Y's Purchase Intention: A Study in Ho Chi Minh City, International Journal of Trade, Economics and Finance, 6(4), 191-198.

- Theodossiou, G. \& Chrisa, K. (2007). Marketing Research Merely Reflects the Needs and Wants of Consumers, American Journal of Applied Sciences, 4(8), 578-591.

- Tomanek, M. (2020). Ambush Marketing and RTM as a Dangers for Sport Organisations, Journal of Physical Education and Sport, 20(2), 1130-1135.

- Tümer, M., Aghaei, I., Oney, E. \& Nasser Eddine, Y. (2019). The Impact of Traditional and Social Media Marketing on Customers' Brand Trust and Purchase Intentions in the Turkish Airlines Market, Journal of Research in Emerging Markets, $1(4), 55-68$.

- Ujwala, B. (2012). Insights of Guerrilla Marketing in Business Scenario, International Journal of Marketing, Financial Services and Management Research, 1(10), 120-128.

- Wendland, L. (2016). A Common Ground in Guerilla Marketing: State of Research and Further Research Opportunities, Junior Management Science, 1, 34-59.

- Williams, P. (2018). Rebel Guerillas: Mosby, Quantrill and Anderson, McFarland and Company Inc, Jefferson, North Carolina, USA.

- Yüksekbilgili, Zeki. (2014). The Use of Guerilla Marketing in SMEs, International Journal of Advanced Multidisciplinary Research and Review, 2(2), 2-7.

- Yuniarto, T., Adi, P. A., Setyanto, R. P. \& Kaukab, M. E. (2020). Guerilla Marketing of Covid-19 Healthy Measures, Palarch's Journal of Archaeology of Egypt/Egyptology, 17(7), 10661-10677. 


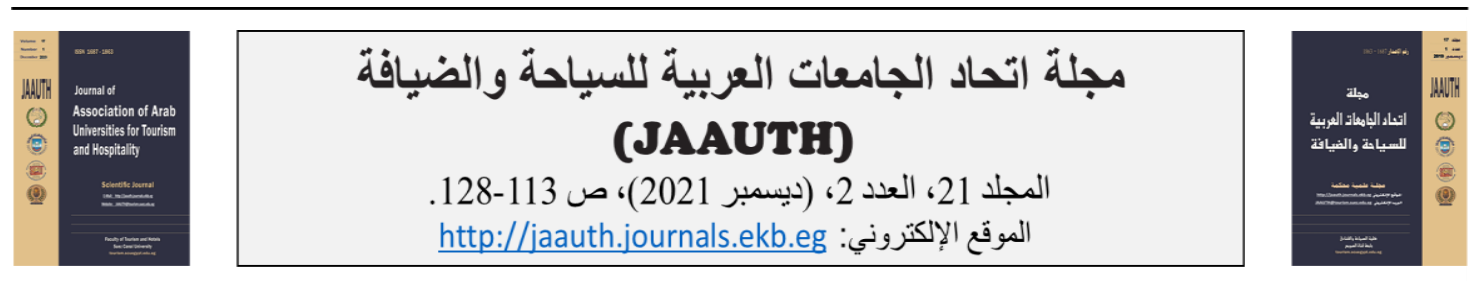

\section{دور تطبيق التسويق الجوريلا في زيادة الحصة السوقية لمصر للطيران للخطوط الجوية}

أحمد عادل حماد

مدرس بقسم الاراسات السياحية، كلية السياحة والفنادق، جامعة المنصورة

\begin{tabular}{|c|c|}
\hline الملخص & معلومات المقالة \\
\hline 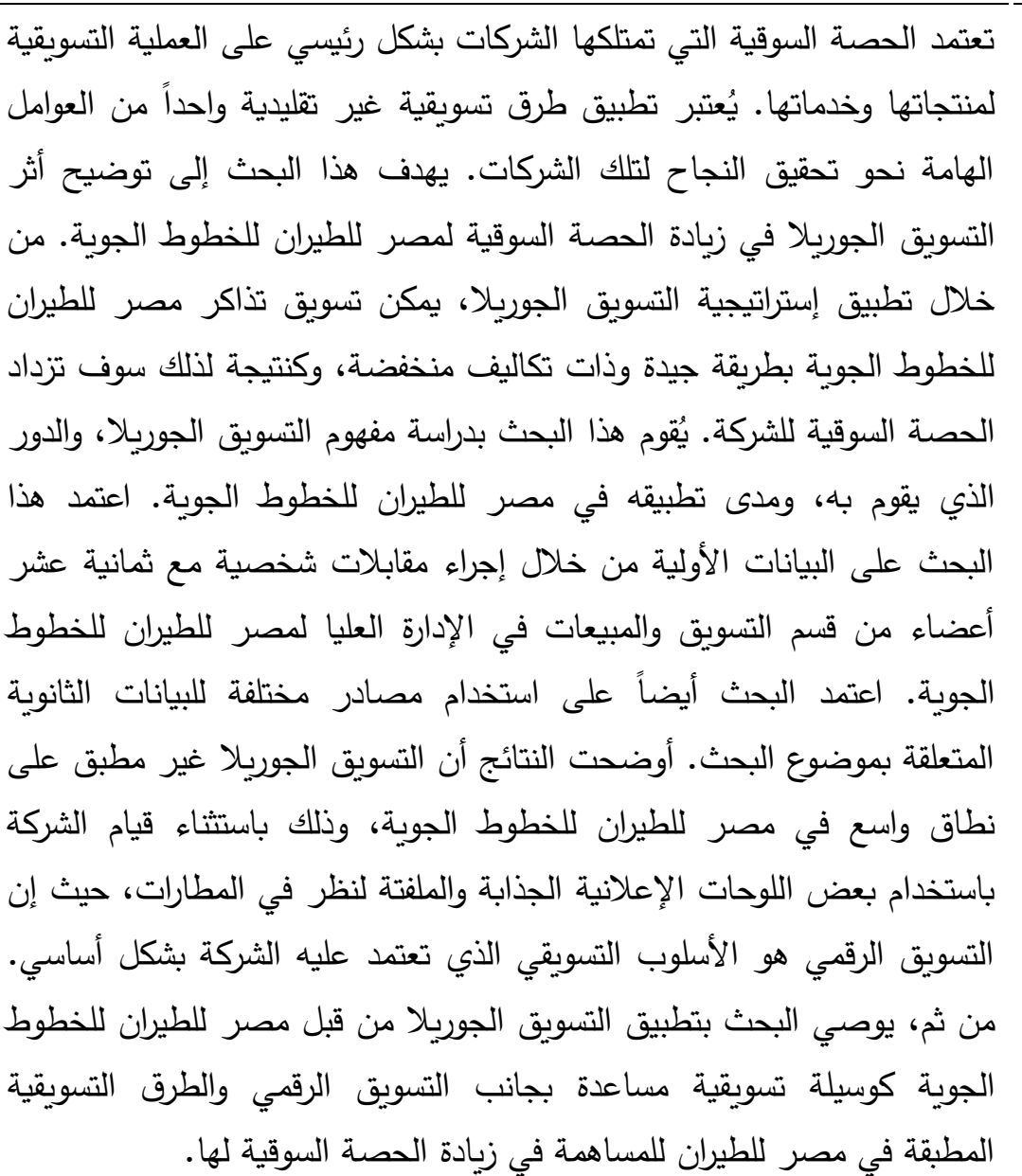 & 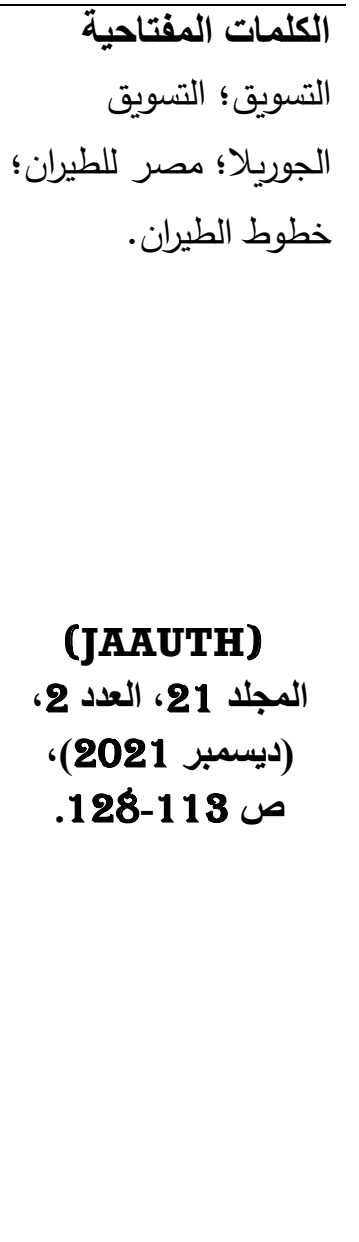 \\
\hline
\end{tabular}

